\title{
Lighting policy as an integral part of sustainable urban planning
}

\author{
Agata Łopuszyńska \\ e-mail: agata.lopuszynska@pwr.edu.pl \\ Magdalena Belof \\ e-mail:magdalena.belof@pwr.edu.pl \\ Katedra Urbanistyki i Procesów Osadniczych, Wydziat Architektury, \\ Politechnika Wrocławska, ul. Prusa 53/55, 50-317 Wroctaw
}

\begin{abstract}
The aim of the paper is to describe an evolution of approaches to regulation of artificial light in urban areas and present examples of existing practices in this regard. The authors introduce the theoretical debate on the lighting pollution phenomenon and outline the contemporary arguments for lighting planning as an element of broader urban policy. Presented examples of comprehensive approaches to urban light planning have been based on the results of international inquiry curried out in 2018.
\end{abstract}

Key words: urban lighting, illumination masterplan, light pollution, comprehensive sustainable urban planning, lighting policy

\section{Introduction}

Modern cities are drowning in a sea of artificial light. The phenomenon of a 24-hour city has been labelled in scientific literature as the an end of the night [Bogard 2013] or even a nyctophobia of western cities [Ederson 2015]. Merely 150 years of electrical lighting has made humanity accustomed to the comfort of brightness after dark. A change in the urban lifestyle has already become evident in the city nightscape and the brightness of urban spaces have grown into one of the highest values for urban communities. Public space has become accessible at any time without any restrictions and for everyone, giving a psychological comfort and a democratic sense of security [Brandi, Geissmar-Brandi 2007]. The real value of artificial lighting is the possibility to individualize one's lifestyle and remain active during the time of natural darkness. This phenomenon has been named "a time sprawl" and in in the Polish literature is also known as "the night-time urbanization" [Rozwadowski 2007].

Recent decades have brought about the development of an outdoor lighting at an unprecedented scale. Light is no longer used solely to maintain the public space or improve its accessibility after dark, but also to aestheticize and commercialize it, by expanding its visual attraction, improve orientation and stress identity of places [Martyniuk 2014]. Lighting still plays a dominant role in road lighting, becoming more and more intense as urban technical infrastructure develops. Light is also used to strengthen the subjective sense of security through private outdoor lighting of workplaces, apartments or industrial plants.

The increase of the night-sky brightness, as a result of urbanized areas expansion, reflects not only the scale, but also the approach to lighting planning of such areas [Walker 1977]. Artificial brightness has quickly became a symbol and a determinant of distinction between cities and provinces, however, the problem of light pollution is severe even for relatively small settlement units [Kyba et al. 2017].

Acknowledging the role and value of electric lighting, which is one of the most important motors of our civilization, it is necessary to admit that the need to establish basic principles for its use is stronger than ever. Cities have to face a problem of lighting excess and visual effects no longer dominate the discussion of urban 
lighting policy, including today also the issues of energy efficiency or dark sky preservation. Therefore lighting regulations become more and more precise and turn into an integral part of sustainable city planning.

\section{Overabundance of artificial light and definition of light pollution}

Although the widespread usage of artificial light at night is strongly associated with high quality of life, safety and modernity, the average global increase of artificial brightness is estimated at 6\% per year [Holker 2010]. The first widely known reports about the harmfulness of light excess had already been noted in the 1970s [Ściężor 2010]. Meanwhile, the rapid evolution in lighting technology and massive access to electricity combined with its falling prices, have contributed to the increasingly unreflective use of light, and thus - successive brightening of the night. The phenomenon was defined as light pollution. Initially, the term was adopted by astronomers, when the lights started to make observations impossible in previously useful locations. The term also began to infiltrate to biological sciences, where the phenomenon was known as photopollution [Ściężor 2010] and meant the negative impact of artificial lighting on living organisms. Initially, both terms were used separately but later, the light pollution became widely used, signifying the general nuisance caused by improper or excessive use of light.

Inaccuracies concerning outdoor lighting may directly affect residents and urban space users, also causing harm to urban ecosystems. The negative effects are most commonly generated by:

- light trespass - the spill of light from areas intentionally illuminated to those that do not require or need it;

- glare - emitting too strong light stream affecting badly one's sight; particularly harmful to pedestrians, drivers and animals causing physical and psychological discomfort; may also endanger the road safety;

- light clutter - excessive concentration of light sources or their thoughtless distribution, e.g. light advertisement, which disrupts spatial order and orientation in the night.

Moreover, each lighting fixture that directs light above the horizon, contributes to its dispersion in the lower atmosphere, forming the so-called sky glow. Improperly directed light is noticeable with a naked eye and can be even more severe on foggy and cloudy nights. The nuisances caused by incorrect lighting can be related to various factors [Kolomański 2015]:

- intensity - when the lights are brighter than necessary or recommended in a given place, used in too a great quantity or operating even when it is completely useless;

- direction - when the light is incorrectly focused: it shines upwards or sideways, beyond the verges of a surface intended for illumination (e.g, street lamps illuminating not only the road and the sidewalk, but also bedroom windows);

- inadequate parameters - when the emission spectrum (color temperature) of lamps is incorrect, which affects the living organisms ${ }^{1}$.

\section{Arguments for lighting regulations}

There are places where the problem of excessive light has already been recognized and where various form of sorting it out have been implemented focusing on its various aspects. Some regulations apply to protection of the sky darkness, other to promotion an effective, but sustainable forms of city lighting. Mostly they are a reactionary responses to specific problems or to the citizen's initiatives in a given areas and their scope and strength depend on the location, demographic and economic circumstances and the level of social awareness.

Currently, the most common motivation for applying the regulations in the field of urban lighting is an intention to reduce energy consumption. However, the modernization carried out solely for the sake of cost reduction can be a threat to the lighting quality. There is a risk that the adoption of the cheapest solutions 
focused only on meeting technical standards ${ }^{2}$ will effect e.g. in installation of sources of a too cold color temperature and being schematically (carelessly) placed. Yet, the scientific researches indicate that as much as onethird of lighting expenses can be saved only through appropriate lighting direction [IDA 2011]. In recent years the environmental factors come to the fore in the debate on conscious urban lighting, above all a postulate of maintaining balance in urban ecosystems, but also the energy cut leading to reduction of a carbon footprint. Additionally the advocates of advertent urban lighting raise arguments of protection of human health and issues of the circadian rhythm disturbance of both humans and animals. Also the cultural-sensual aspect is being heard, what stands for the preservation of the starry night landscape. The latter relates especially to astronomical observations areas, both for scientific or hobby activity, as well for development of astrotourism.

In the actions related to pro-savings regulations, the self-governments play the most important role. Another category of interventions, which cities are more willing to decide on, is an intentional creation of nightscapes and images with light. However, it is worth noting that more and more often at the initiatives of urban lighting transformation are rooted in the individual and societal initiatives and interventions. They are most often focused on eliminating direct nuisances, that origin from lighting environment, addressing the problems of visual comfort, safety and aesthetics of public space lighting, pointing out the "lighting terror" of commercial activity in the space, such as aggressive light signs and advertising or architectural objects illumination.

In most places the city lighting regulation is not yet an element of statutory planning and not even a standard practice. In common modernization plans, it is difficult to find examples of interdisciplinary and comprehensive approaches and technical-economic orientation to light planning too often results in over mechanistic and replicable selection and deployment of light sources.

The actions aimed at establishing outdoor lighting principles, present two basic approaches [Nawalkowski 2013]. The first aims at darkness protection of particular areas and mainly propose preventive actions maintaining the excellent quality of the night sky measured by the brightness levels and visibility of the stars (especially by visibility of the Milky Way) (Fig. 1.). Such areas are often incorporated into the nature and landscape reserves boundaries and their protection often requires buffer regulations in the neighborhood zones to limit the possibility of adverse effects of their lights. The second approach aims at darkness restoration and applies to areas where it has been decided to minimize already perceptible pollution. The night sky quality in these areas does not have to be perfect, but significantly better than an average. The goal of undertaken actions is to reverse the negative effects of irrational lighting policy, thus are mainly carried out in urbanized areas: whole cities, their selected districts or rural and suburban areas, however there is not much evidence so far that such attempt cover the whole areas of big cities.

Representatives of such areas already form world-wide cooperation networks such as the International Dark Sky Communities, certified by the International Dark Sky Association or the Urban Star Parks in Canada [RASC 2016] (Fig. 2.).

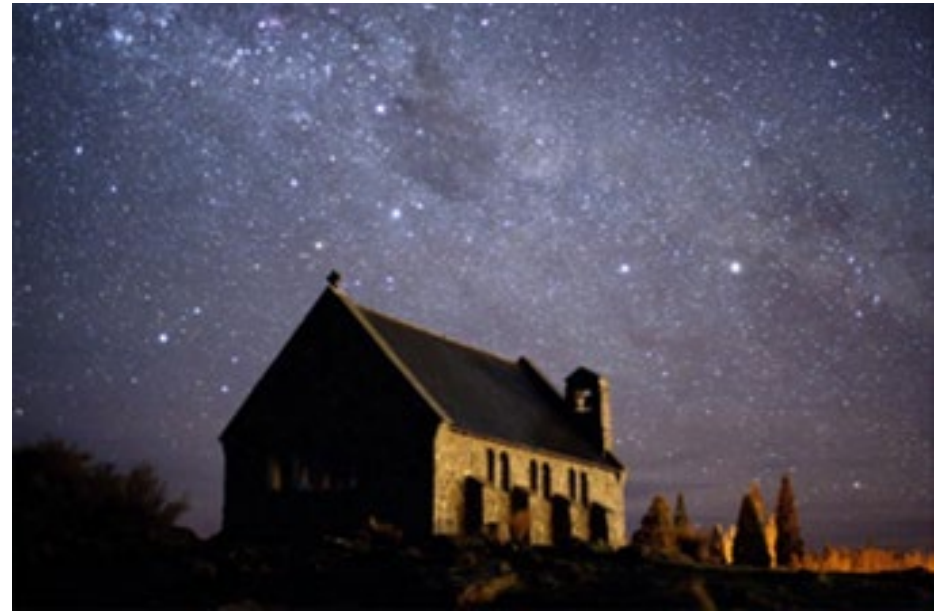

Fig. 1. Aoraki Mackenzie International Dark Sky Reserve [photography by Fraser Gunn]. Międzynarodowy Rezerwat Ciemnego Nieba „Aoraki Mackenzie” [fot. Fraser Gunn]. 


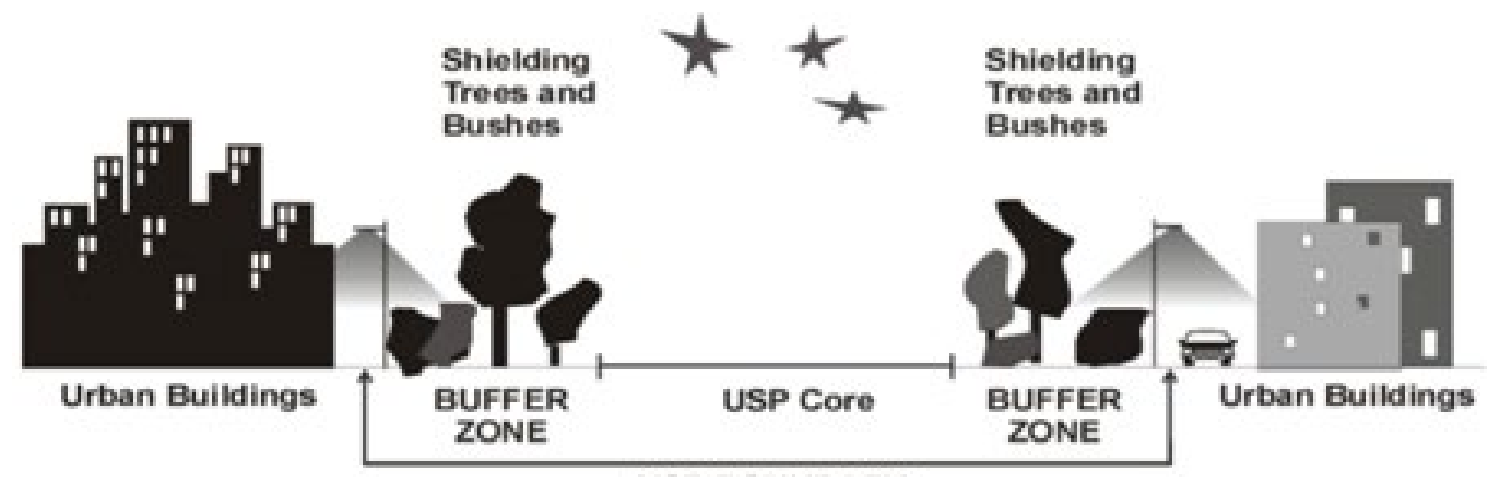

USP BOUNDARY

Fig. 2. Urban Sky Park layout [Guidelines for Outdoor Lighting 2016, Royal Astronomical Society of Canada]. Schemat Miejskiego Parku Nieba [Guidelines for Outdoor Lighting 2016, Royal Astronomical Society of Canada].

\section{Technical regulations of excessive and improper lighting}

Presently, no uniform method of urban lighting planning and regulation exists. The instruments used depend on the type, motives and competences of entities implementing projects, also on the sources and forms of financing, legal standards and even social attitudes. The lighting projects may take a form of broader urban plans aimed at systemic transformations in the longer perspective, or strictly technical documentation targeted at the "here and now" fragmentary tasks. However, regardless the project nature, they have a common basis in the form of generally recognized international guidelines and recommendations, including most commonly used standards and publications by International Commission on Illumination [CIE 2003, 2017], Institution of Lighting Professionals [ILP 2011], International Dark-Sky Association [IDA 2011] or International Astronomical Union [IAU 2009]. Apart from technical standards like the photometric parameters, space brightness thresholds etc., they offer a set of simple rules and recommendations for proper lighting planning, i.e. rules for lighting direction, color of temperature or zoning.

One of the first steps towards the comprehensive urban lighting plan, is a reduction of light emission above the horizon. This is an effective way to reduce the urban glow and the light trespass, some research show that if only $1 \%$ of lighting devices emit light above the horizon this can cause up to $100 \%$ rise of a glow [Mohar]. It is also estimated that at least $80 \%$ of pollution caused by the emission of light to the upper hemisphere, can be reduced in a manner imperceptible to humans (in terms of change in the brightness level of illuminated spaces). To control the direction of light it is necessary to properly select and install the luminaires which prevent its spilling and shorten the route of diffusion in the atmosphere. The awareness of this mechanism grows, for example, the lamp manufacturers already provide their products with an appropriate ULOR indicator (Upward Light Output Ratio), which helps making right planning decisions. The height and distance of the light sources should be carefully adjusted to the illuminated surfaces and the lamps can be equipped with power reductors, timers and, in justified cases, motion detectors. This allows for differentiation of lighting, depending on the needs and functional requirements of a given areas which is particularly important in places where lighting causes spatial conflicts but also in architectural illuminations which often diffuse powerful beams of light high above the city silhouette. Relevant illuminance is also important, but most of existing legal regulations indicate only minimum luminance levels while lighting brightness should be adjusted to the type of place and the activities it serves to. Next to the lighting device and intensity parameters also the light color is just equally important. Scientific research indicates that lighting should have as low as possible light emission in the blue and violet range of spectrum [IDA 2010]. The healthiest, in many respects, is the color temperature below the value of $2700 \mathrm{~K}$, i.e. the perceptible colors of warm white to orange. But not only the argument of proper circadian rhythm matters in this respect: it has already been noticed that replacement of traditional light solution into LED drastically increases the brightness of a city space [DW 2017]. The wave with the length responsible for blue tones, tend to be more easily scattered in the atmosphere, intensifying the hostile phenomenon. 


\section{Lighting master plans as an urban policy tool}

The technical rules for limiting the phenomena of light excess are relatively simple, however the comprehensive urban lighting plan must take into account not only technical aspects, but also social, legal, technological or image-related factors. Therefore it is not only a compliance of recognized norms but much more challenging planning endeavor.

The 'Capital Illumination Plan 2017-2027' [NCC 2017] is an example of comprehensive approach to urban lighting planning which covers the central area of the Canadian National Capital Region on both sides of the Ottawa River - connecting Quebec and Ontario. The main intention of the plan was to create a coherent image of the city after dark, because of a noticeable gap in the perception of the day- and night-time city space as a result of lighting chaos. The outdated technology delivered additional arguments for urban lighting reorganization, however the emphasis was placed on its quality, in particular in public spaces.

The plan regulates, among other things, the color of light and its operating time. The most recommended color of light is, simply, white, especially warm white tones for the street lighting, green areas and waterways. For compositional reasons, warm white is also favored for the foreground, and cool white for the background of urban panoramas (Fig. 3.). According to the concept, the use of colour lighting is limited to areas of innovation and art, nightlife zones and temporary illuminations. Also, light flashing and the use of lighting for commercial and marketing purposes are unwelcomed.
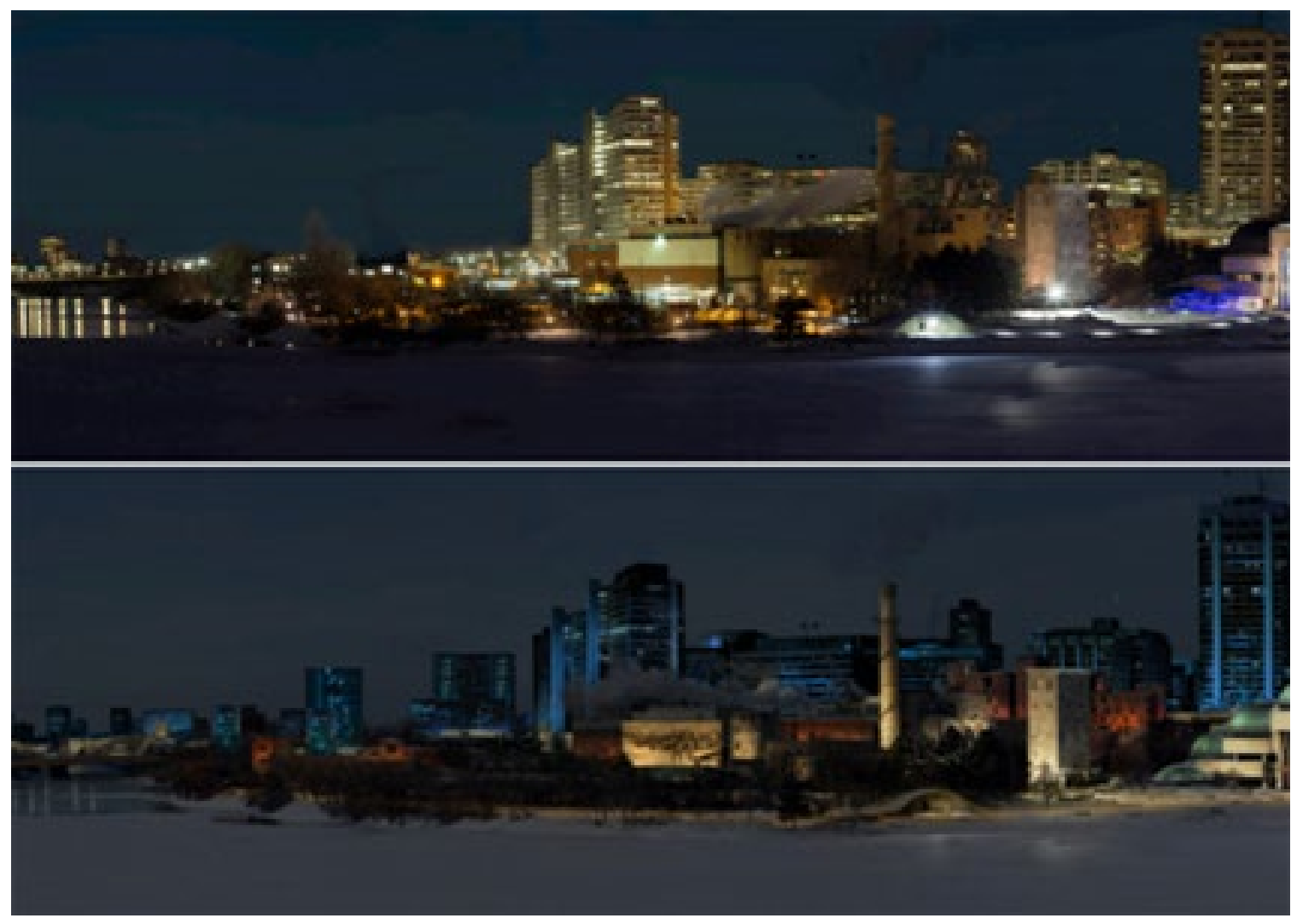

Fig. 3. Existing conditions (upper) and visualization of conceptual future panorama of Gatineau [Capital Illumination Plan 2017-2027, National Capital Commission 2017].

Obecne uwarunkowania (na górze) i wizualizacja koncepcji przyszłościowej panoramy Gatineau [Capital Illumination Plan 2017-2027, National Capital Commission 2017]

The key instrument used in the plan is the delineation of balanced lighting zones of illumination and dark, for which separate guidelines have been elaborated (Fig. 4.). The illumination zones concentrate around the central part of the Ottawa River, and are divided into the inner and outer loop of the boulevards and their close 
and distant landscape setting. For the two central illumination parts, where particular focus should be placed on heritage objects and national symbols, the amber and warm white tones of light (2200-3200 K) are preferred. Plan also recommends to turn off the internal office lights outside working hours, and to create visual connections along the roads leading to the indicated nightlife areas. For the 'background' zones, in turn, warm tones of light were designated for historic buildings while neutral white (3500-4000 K) for contemporary buildings. The cool white $(4200 \mathrm{~K}+)$ is reserved for other architectural landmarks and details specified in the plan. Their choice needs to be justified by, i.a. significance for the cultural landscape of the city, relation with public space and limitations of facade materials in terms of physical response to light. Also, the light beams of such illuminations are recommended to be directed to impenetrable elements of the objects, i.e. walls or cornices. In accordance with the plan, ground lighting cannot contribute to pedestrian glare - all the public lighting will be equipped with opaque lamp covers limiting the beam of light to a maximum angle of 80 degrees. The waterways areas (along with their 10-meter buffer) and green areas (parks and shorelines) are considered to be dark zones. The argument for diminish the lights was to minimize their harmful effects on fauna and flora but also to provide the contrast necessary to highlight central illuminated places and selected dominants.

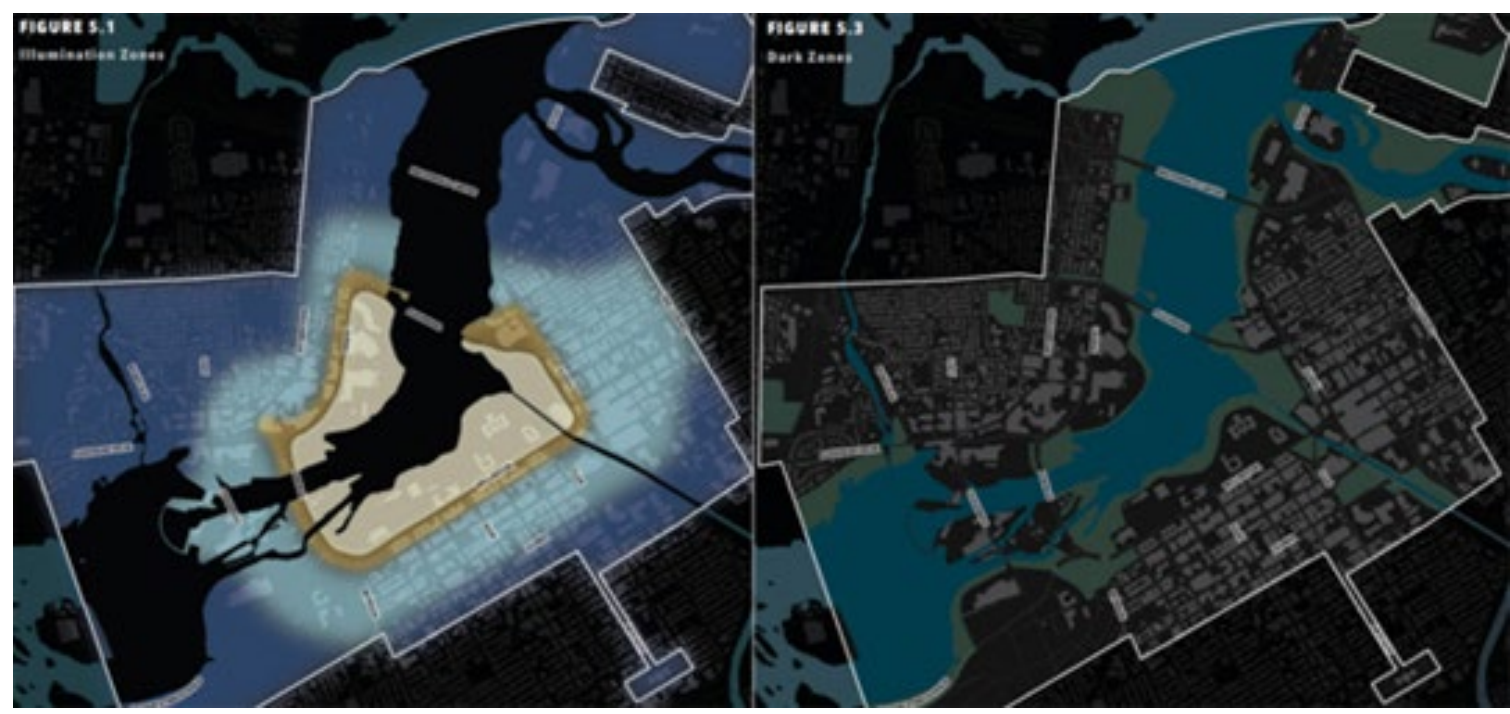

Fig. 4. A concept of illumination and dark zones [Capital Illumination Plan 2017-2027, National Capital Commission 2017]. Założenie stref iluminacji i stref ciemności [Capital Illumination Plan 2017-2027, National Capital Commission 2017].

In the dark zones, the plan assumes keeping the lighting levels on minimum, except for the designated places, such as landmarks, most visited paths, intersections of transport routes and places important for tourism, like monuments and cruises routes. The lamps cannot contribute to the light trespass, therefore its luminaires need to be shielded and the warmest colors of light are recommended (up to $3000 \mathrm{~K}$ ). Also, the intensity of light should be reduced at the watersides, because its brightness is intensified by reflections, similarly in the case of snow cover in winter. The plan recommends protection of green spaces, favouring subtle lighting at night, even allowing the use of dense foliage plants shrubberies as a barrier.

An important part of sustainable lighting is the ability to adjust levels and time of lighting operation. The master plan recommends the light sources operating time, attributing the appropriate limits to given groups of lighting sources (Tab. 1.). At the same time, an individual approach to each place in agreement with the interested parties is advised. For the low-traffic spaces, a suggested solution is a motion activated lighting (such as parking lots, backyards, parks, recreational paths, etc.). 
Table 7. Lighting Curfew Parameters [selected representative modes from Capital Illumination Plan 2017-2027, National Capital Commission 2017].

Parametry wygaszania oświetlenia [wybrane reprezentatywne tryby z Capital Illumination Plan 2017-2027, National Capital Commission 2017].

\begin{tabular}{|c|c|c|}
\hline Mode & Description and Potential Uses & Recommended Parameters \\
\hline $\begin{array}{l}\text { Permanent } \\
\text { Functional } \\
\text { Lighting }\end{array}$ & $\begin{array}{l}\text { Functional lighting requiring } \\
\text { activation for the entire night } \\
\text { (e.g., streets, major pathways, } \\
\text { public places, health and } \\
\text { safety services and so on). }\end{array}$ & $\begin{array}{l}\text { Activation at sunset. } \\
50 \% \text { reduction in intensity from midnight to } 5 \mathrm{am} \text {. }\end{array}$ \\
\hline $\begin{array}{l}\text { Public Transit } \\
\text { System } \\
\text { Lighting }\end{array}$ & $\begin{array}{l}\text { Lighting related to public } \\
\text { transit networks (stations and } \\
\text { associated infrastructure). }\end{array}$ & $\begin{array}{l}\text { Activation at sunset. } \\
50 \% \text { reduction in intensity during off-peak hours. } \\
\text { Fully deactivated when public transit services end. }\end{array}$ \\
\hline $\begin{array}{l}\text { Illumination } \\
\text { Lighting }\end{array}$ & $\begin{array}{l}\text { Illumination to enhance } \\
\text { the nighttime landscape } \\
\text { (e.g. buildings, commemorative } \\
\text { monuments, public art and so on). }\end{array}$ & $\begin{array}{l}\text { Activation at sunset. } \\
\text { Lower intensity and reduced amount of lighting, if } \\
\text { not total deactivation, starting between midnight } \\
\text { and } 2 \text { am (based on location and use). } \\
\text { On a case-by-case basis for the most important ele- } \\
\text { ments of the nighttime scenery, as identified in the } \\
\text { illumination concept (see Chapter 5): } \\
\text { Activation at sunset. } \\
\text { Illumination in "night mode" starting at midnight } \\
\text { ("night mode" involves a specific lighting design } \\
\text { that lowers light in a gradated operation or by par- } \\
\text { tial deactivation). }\end{array}$ \\
\hline $\begin{array}{l}\text { Dark Zone } \\
\text { Lighting }\end{array}$ & $\begin{array}{l}\text { Lighting dedicated to areas } \\
\text { identified as dark zones } \\
\text { (see Section 5.2.1). }\end{array}$ & $\begin{array}{l}\text { Activation at sunset. } \\
\text { nower intensity and reduced amount of lighting, if } \\
\text { noctivation, at } 10 \text { pm. }\end{array}$ \\
\hline
\end{tabular}

The plan stresses that energy efficiency and lighting quantity cannot take precedence over its quality, and that lighting should always correspond with the individual features of each location and surroundings.

Another example of comprehensive document on lighting planning is the 'Collier County Lighting Standards' from 2017 [CCLT 2017]. It provides supplementary guidance to the existing fragmentary legal regulations and presents an integrated approach to the illumination in Collier County, Florida. The main objective of the plan is to enhance a sense of comfort and security in public space and to respect natural environment and the dark sky.

One of the basic concepts of Collier Lighting Standards is the adoption of lighting zones that represent 'the desired ambient light levels of a community' [CCLT 2017, p. 11]. This approach introduces an element of flexibility to fairly restrictive regulations. Based on definitions taken from recognized standards [IDA MLO 2011], all areas and objects owned and maintained by the County, have been categorized into specific zones. Zone " 0 " is the most rigorous and its users have to accept the adaptation to total darkness. Another - zone " 1 ", of low ambient lighting - provides lighting only for safety or comfort and allows lack of brightness continuity. Zone " 2 " is an area of human activity of a moderate light levels. The last zone, " 3 " includes moderately high level of brightness, where the lighting is spatially continuous and usually uniform. Even though the $2^{\text {nd }}$ and $3^{\text {rd }}$ zone allow the cooler light tones (up to 3500 and $4800 \mathrm{~K}$ ), it is recommended that the users voluntarily use the lamps of a color temperature below $3000 \mathrm{~K}$, leaving the cold light only for sensitive areas (Tab. 2.).

The document contains information and recommendations related not only to the parameters, but also to installation and placement of light sources. In particular it draws attention to areas that require special care in preventing the effects of light spill-off onto unwanted surfaces, glare and sky glow. They include, among 
others, the residential and landscape zones as well as the surroundings of architectural illuminations. It is recommended to direct illumination fixtures downward to reduce its intensity and use full shielding.

It is worth noting that the approach to the minimum levels of lighting is different, from those known i.a. in Poland: the standards clearly indicate that outdoor lighting should not exceed the minimum levels specified by photometric characteristics. This may be considered as too much stringent mechanism, yet Collier vision is to become a state and national leader in applying lighting standards for the community.

Table 8. Lighting Zone Classification and Lighting Zone-Based Restrictions [Collier County Lighting Standards 2017, Collier County Government]

Klasyfikacja stref oświetleniowych i odpowiadające im ograniczenia [Collier County Lighting Standards 2017, Collier County Government]

\begin{tabular}{|c|c|c|c|c|}
\hline \multicolumn{2}{|c|}{ Lighting Zones } & \multicolumn{3}{|c|}{ Site and Structure Classification } \\
\hline \multicolumn{2}{|c|}{$\begin{array}{l}\text { LZO } \\
\text { No Ambient Lighting }\end{array}$} & \multicolumn{3}{|c|}{$\begin{array}{l}\text { Beaches; Boat Launch Sites; Cemeteries; Nature Trails \& Pathways; Parks - } \\
\text { Neighborhood; Preserves; Remote Utility Stations; Wellfields. }\end{array}$} \\
\hline \multicolumn{2}{|c|}{$\begin{array}{l}\text { LZ1 } \\
\text { Low Ambient } \\
\text { Lighting }\end{array}$} & \multicolumn{3}{|c|}{$\begin{array}{l}\text { Campuses - Rural; Fueling Stations - Rural; General Office Buildings; Landfills; } \\
\text { Museums; Recycling Centers; Outdoor Swimming Pools; Parking Lots \& Garages - } \\
\text { Urban; Parks - Community; Roadways - Local, Rural Collectors; Water Parks - Rural. }\end{array}$} \\
\hline \multicolumn{2}{|c|}{$\begin{array}{l}\text { LZ2 } \\
\text { Moderate Ambient } \\
\text { Lighting }\end{array}$} & \multicolumn{3}{|c|}{$\begin{array}{l}\text { Airports - Rural; Corrections Facilities - Rural; Fueling Stations - Urban; Master } \\
\text { Pump Stations; Parking Lots \& Garages - Urban; Parks - Regional; Roadways - } \\
\text { Rural Arterial, Urban Collectors; Temporary Events - Rural; Water \& Wastewater } \\
\text { Plants - Rural; Water Parks - Urban. }\end{array}$} \\
\hline \multicolumn{2}{|c|}{$\begin{array}{l}\text { LZ3 } \\
\text { Moderately High } \\
\text { Ambient Lighting }\end{array}$} & \multicolumn{3}{|c|}{$\begin{array}{l}\text { Airports - Urban; Campuses - Urban; Corrections Facilities - Urban; Roadways - } \\
\text { Urban Arterial; Temporary Events - Urban; Water \& Wastewater Plants - Urban. }\end{array}$} \\
\hline $\begin{array}{l}\text { Lighting } \\
\text { Zones }\end{array}$ & \multicolumn{2}{|c|}{$\begin{array}{l}\text { Color Temperature CCT } \\
\text { Allowed Range }\end{array}$} & $\begin{array}{l}\text { Light Reduction } \\
\mathrm{R}=\text { Required } / \mathrm{V}=\text { Voluntary }\end{array}$ & $\begin{array}{l}\text { Maximum Light } \\
\text { Output Percentage }\end{array}$ \\
\hline LZO & \multicolumn{2}{|c|}{$1900-3000 \mathrm{~K}$} & $\mathbf{R}-\mathbf{1}$ Hour after close of business & $25 \%$ \\
\hline LZ1 & \multicolumn{2}{|c|}{$1900-3000 \mathrm{~K}$} & $R-11 \frac{1}{2}$ Hours after close of business & $25 \%$ \\
\hline LZ2 & \multicolumn{2}{|c|}{$1900-3500 \mathrm{~K}$} & $\mathbf{R}-\mathbf{2}$ Hours after close of business & $50 \%$ \\
\hline LZ3 & \multicolumn{2}{|c|}{$1900-4800 \mathrm{~K}$} & V - $\mathbf{2}$ Hours after close of business & $50 \%$ \\
\hline
\end{tabular}

\section{Conclusions}

The approach to urban lighting has already gone far beyond sole utility and nowadays the attention is more and more being paid to the issues related to its overabundance. The first reaction to the nuisance resulting from light pollution was establishing a set of rules for the proper lighting use and the corresponding parametric standards. Initially, the dark-sky protection was considered as a priority issue, but ongoing improper use of lighting resulted in identification of many lighting-related conflicts in urbanized spaces. The first attempts to implement comprehensive lighting regulations already appear in urban planning practice, however the complexity of the issue may be proved by the fact that such plans so far not covered areas of large cities.

Minimizing light pollution becomes significantly complicated in perspective of the requirements and rights that must be applied in populated areas - introducing substantial changes is difficult there, both for formal as well as social reasons. However, the lighting modernization opens an opportunity for cities to substantially improve quality of life standards by better adjustment of spaces to the needs of the users, while at the same time minimizing the bad impact on the environment and cost cutting.

The question: 'what exactly compose a high quality of urban lighting?' has not been resolved definitively and universally yet, but with no doubt it is a multidimensional issue. The most advanced and coherent form of searching for the city lighting quality are illumination master plans. Such projects not only aim to provide 
conditions for visibility, safety and aesthetics of the night space, but also respond to global problems, postulating reduction in electricity consumption and seeking a balance between the light and dark spaces. Already known practices in urban light planning differ substantially regarding methodological approaches, hierarchy of priorities and policy implementation instruments. Currently, most of regulations seem to be limited to public spaces, but also they include good examples and an some form of incentives to apply regulations in the private sector. As technology develop and social awareness continue to grow, such urban policy tools can be expected to become more popular as the integrated element of urban policy in the near future.

\section{References}

[1] Bogard P., 2013: The End of Night: Searching for Natural Darkness in an Age of Artificial Light. Hachette UK.

[2] Brandi U., Geissmar-Brandi C., 2007: Light for cities. Lighting design for Urban Spaces. A Handbook. Birkhauser, Basel, Switzerland.

[3] CCLT, 2017: Collier County Lighting Standards. County-Wide Lighting Team. Collier County, Florida.

[4] CIE, 2017: Guide on the Limitation of the Effects of Obtrusive Light from Outdoor Lighting Installations, $2^{\text {nd }}$ Edition. Publication no. 150, Vienna, Austria.

[5] DW, 2017: LED-technology increases light pollution across the night sky. Deutsche Welle. https://p.dw.com/p/2o7jA (21.08.2018).

[6] Ederson T., 2015: The gloomy city. Rethinking the relationship between light and dark. Urban Stud. 52(3), 422-438

[7] Holker F. et al., 2010: Light pollution as a biodiversity threat. Trends Ecol. Evol. 25(12), 681-682.

[8] IAU, 2009: Resolution B5 in Defence of the night sky and the right to starlight. XXVIIth General Assembly, Rio de Janeiro, Brazil.

[9] IDA, 2010: Visibility, Environmental and Astronomical Issues Associated with Blue-Rich White Outdoor Lighting. International Dark-Sky Association, Tucson-Washington.

[10] IDA 2011, Light Pollution Wastes Energy and Money. http://darksky.org/light-pollution/energy-waste/ (21.08.2018).

[11] IDA-IES, 2011: Joint IDA-IES Model Outdoor Lighting Ordinance (MLO) with user's guide. International Dark-Sky Association/Illuminating Engineering Society

[12] ILP, 2011: Guidance notes for the reduction of obtrusive light. Publication no. GN 01. Institution of Lighting Professionals.

[13] Kołomański S., 2015. Zanieczyszczenie światłem i ciemność. Prace i Studia Geograficzne 53, 29-46.

[14] Kyba Ch.C.M. et al., 2017: Artificially lit surface of Earth at night increasing in radiance and extent. Sci. Adv. 3(11).

[15] Martyniuk-Pęczek J., 2014: Światła miasta. Marina, Wrocław.

[16] Mohar A., 2018: Causes of light pollution. Managing security, ignorance, profit, corruption. LightPoll 2018, The First Vobanista Workshop on Light Pollution. Fruska Gora, 26.05.2018, Serbia.

[17] Nawalkowski P., 2013: Problem zagrożenia światłem. Dzikie życie. 11(233), 11-13.

[18] NCC, 2017: Capital Illumination Plan 2017-2027. National Capital Commission. Ottawa, Canada.

[19] RASC 2016: Guidelines for Outdoor Lighting in Urban Star Parks (RASC-USP-GOL). Royal Astronomical Society of Canada Dark Sky Preserve Program. .

[20] Rozwadowski T., 2007: Time sprawl: czy zagraża nam urbanizacja nocy? Urbanista. 5(53), 27-29

[21] Ściężor T. et al., 2010: Zanieczyszczenie świetlne nocnego nieba w obszarze aglomeracji krakowskiej: analiza pomiarów sztucznej poświaty niebieskiej. Wyd. Polit. Krak. Kraków.

[22] Stevens R.G., Zhu Y., 2015: Electric light, particularly at night, disrupts human circadian rhythmicity: is that a problem?." Phil. Trans. R. Soc. B 370.1667 (2015): 20140120. 


\section{Lighting policy as an integral part of sustainable urban planning}

Streszczenie: Celem artykułu jest opisanie ewolucji podejścia do regulacji sztucznego światła na obszarach miejskich oraz przedstawienie przykładów istniejących praktyk w tym zakresie. Autorki prezentują teoretyczną debatę na temat zjawiska zanieczyszczenia światłem i przedstawiają współczesne argumenty przemawiające za planowaniem oświetlenia jako elementu szerszej polityki miejskiej. Przedstawione przykłady kompleksowego podejścia do planowania oświetlenia miejskiego zostały oparte na wynikach międzynarodowej kwerendy przeprowadzonej w 2018 roku.

Słowa kluczowe: oświetlenie miejskie, masterplan oświetleniowy, zanieczyszczenie światłem, zrównoważone planowanie miast, polityka oświetleniowa. 